\title{
SPESIES COMPOSITION AND DENSITY OF MACROALGAE IN KAMBOWA VILAGE WATERS, SOUTHEAST SULAWESI
}

Ira $^{1}$

\begin{abstract}
Macroalgae has an important role in marine waters both ecologically and economically. This study aims to provide information about spesies composition and density of macoalgae in the Kambowa village waters and the wealth of macroalgae in Southeast Sulawesi. The study was conducted in the waters of Kambowa village,North Buton district South East Sulawesi from November 2015-January 2016. Sampling of macroalgae were done using quadrate transect $\left(\begin{array}{llll}1 & x & 1 & \mathrm{~m}\end{array}\right)$ and other is $10 \mathrm{~m}$ distance and $100 \mathrm{~m}$ length. The result of study found that the number of macroalgae spesies consisted of 16 spesies consisting of 7 orders, 10 families, 13 genera. The spesies composition was dominated by Chlorophyta class (43\%), Phaeophyta class (37\%) and Rhodophyta class (21\%). Total density of macroalgae is 542 ind $/ \mathrm{m}^{2}$ with $229 \mathrm{ind} / \mathrm{m}^{2}$ by Chlorophyta class, and Phaeophyta and Rhodophyta class that is $201 \mathrm{ind} / \mathrm{m}^{2}$ dan $112 \mathrm{ind} / \mathrm{m}^{2}$. The highest density was $144 \mathrm{ind} / \mathrm{m}^{2}$ with Halimeda macroloba. The lowest density was 2 ind $/ \mathrm{m}^{2}$ with Gracillaria edulis.
\end{abstract}

Keywords composition, density, macroalgae, kambowa

Received : 25 Januari 2018

Accepted : 27 Februari 2018

$\left.{ }^{1}\right)$ Fakultas Perikanan dan Ilmu Kelautan Universitas Halu Oleo.

E-mail: irafpikunhalu@gmail.com

\section{PENDAHULUAN}

Salah satu biota laut yang banyak dijumpai hampir di seluruh pesisir, terutama di wilayah pesisir yang mempunyai rataan terumbu karang adalah makroalga. Makroalga merupakan alga yang berukuran besar, dari beberapa $\mathrm{cm}$ sampai bermeter-meter. Secara morfologi, makroalga tidak memperlihatkan adanya perbedaan antara akar, batang dan daun. Seluruh wujud makroalga tersebut seperti batang yang disebut "thallus", hanya bentuknya beraneka ragam. Makroalga juga memiliki substansi yang beragam, ada yang lunak, keras mengandung kapur, berserabut dan lain-lain.

Makroalga termasuk tumbuhan yang berklorofil dan memiliki peranan penting bagi manusia dan perairan laut, dapat digunakan sebagai bahan baku pada industri obat-obatan, tekstil, pasta gigi dan kosmetik (Indriani and Sumiarsih, 1992). Manfaat makroalga sebagai sumber makanan yang kaya akan protein bagi organisme laut maupun manusia, karena mempunyai struktur asam amino lengkap.

Peranan makroalga di perairan laut sebagai penyedia karbonat dan pengokoh substrat dasar sehingga bermanfaat bagi stabilitas dan kelanjutan terumbu karang (Wray, 2009). Menurut, Makroalga (famili calcareous) mengandung kalsit dan aragonite yang dapat membentuk semen sebagai perekat pecahan karang mati sehingga bermanfaat untuk ketahanan terhadap benturan ombak (Dawes, 1981). Fungsi lain makroalga untuk mencegah pergerakan substrat, penyaring 
air dan berperan penting dalam produksi primer di lautan serta sebagai area pembesaran dan pemijahan biota-biota laut dan dapat memproduksi zat-zat organik (Duxbury and Fuxbury, 1989).

Kambowa adalah sebuah Desa yang terdapat di Kabupaten Buton Utara. Buton Utara merupakan sebuah Kabupaten yang terletak di jazirah Sulawesi Tenggara yang meliputi bagian Utara Pulau Buton. Secara umum pantainya terdiri atas batuan dan rataan terumbu yang berupa perpaduan dari kontur berbentuk datar (flat) ke kontur yang tiba-tiba berubah drastis menjadi terjal. Saat surut daerah flatnya terpapar langsung oleh matahari. Selain itu letak pantainya berhadapan langsung dengan Laut Banda. Makroalga yang berada di lokasi tersebut kemungkinan telah beradaptasi dengan kondisi pantai tersebut. Selain itu belum adanya laporan mengenai komposisi jenis dan kepadatan makroalga di perairan Desa Kambowa, sehingga dilakukan penelitian ini agar dapat memberikan informasi mengenai jenis-jenis makroalga yang berada di perairan tersebut, sebagai bagian dari keanekaragaman sumberdaya perairan.

\section{MATERI DAN METODE}

Pengambilan sampel dilakukan di perairan Desa Kambowa 5 01'01" S dan 122 57'30" E (Gambar 1) Kecamatan Kambowa Kabupaten Buton Utara Propinsi Sulawesi Tenggara. Identifikasi sampel makroalga dilakukan di Laboratorium Fakultas Perikanan dan Ilmu Kelautan Universitas Halu Oleo Kendari. Penelitian berlangsung bulan Desember 2015-Januari 2016.

Pengambilan sampel makroalga dan data lain dilakukan saat air laut surut dan mengacu pada metode (English et al., 1997) yang sudah dimodifikasi. untuk ukuran kuadran dan interval jarak. Pengambilan sampel dilakukan dengan menggunakan kuadran (1 x $1 \mathrm{~m}$ ) yang diletakkan pada garis transek sepanjang $100 \mathrm{~m}$, dengan interval $10 \mathrm{~m}$.

Makroalga yang ditemukan dalam kuadran dibersihkan dari substrat, didokumentasikan dan dimasukkan ke dalam kantong plastic, diberi label dan diidentifikasi di laboratorium. Identifikasi makroalga berdasarkan Atmadja et al.
(2006) dan www. algaebase. org (2018). Pengukuran parameter lingkungan yang meliputi parameter suhu (termometer), $\mathrm{pH}$ ( $\mathrm{pH}$ indikator), kecerahan (sechi disk), kedalaman perairan (patok berskala), dan kecepatan arus (floating dredge). Pengukuran dilakukan bersamaan dengan pengambilan sampel makroalga. Data makroalga meliputi komposisi jenis, kepadatan jenis dan frekuensi jenis dianalisis berdasarkan statistik deskriptif.

Komposisi jenis merupakan perbandingan antara jumlah individu suatu jenis terhadap jumlah individu secara keseluruhan. Komposisi jenis makroalga dihitung menggunakan rumus (English et al., 1997).

$K_{i}=\frac{n_{i}}{N} \times 100 \%$

dimana, $\mathrm{K}_{i}$ adalah Komposisi jenis (\%); $\mathrm{n}_{i}$ adalah jumlah individu jenis ke-i; dan $\mathrm{N}$ adalah Jumlah total individu

Kepadatan yaitu jumlah total individu dalam suatu unit yang diukur. Kepadatan makroalga dihitung dengan menggunakan rumus Brower et al. (1998).

$D_{i}=\frac{n_{i}}{A}$

dimana $\mathrm{D}_{i}$ adalah kepadatan spesies untuk spesies $\mathrm{ke}-\mathrm{i}\left(\mathrm{ind} / \mathrm{m}^{2}\right) ; \mathrm{n}_{i}$ adalah jumlah individu jenis ke-i; dan A adalah luas total daerah yang disampling $\left(\mathrm{m}^{2}\right)$

Frekuensi jenis yaitu peluang suatu jenis ditemukan dalam titik sampel yang diamati. Frekuensi jenis makroalga dihitung dengan rumus Fachrul (2007).

$F_{i}=\frac{P_{i}}{\sum P}$

dimana, $\mathrm{P}_{i}$ adalah jumlah petak sampel yang ditemukan jenis ke-i; dan $\mathrm{P}$ adalah jumlah total petak sampel yang diamati

\section{HASIL DAN PEMBAHASAN}

Secara keseluruhan makroalga yang ditemukan ada 16 spesies yang terdiri dari 7 ordo dan 3 


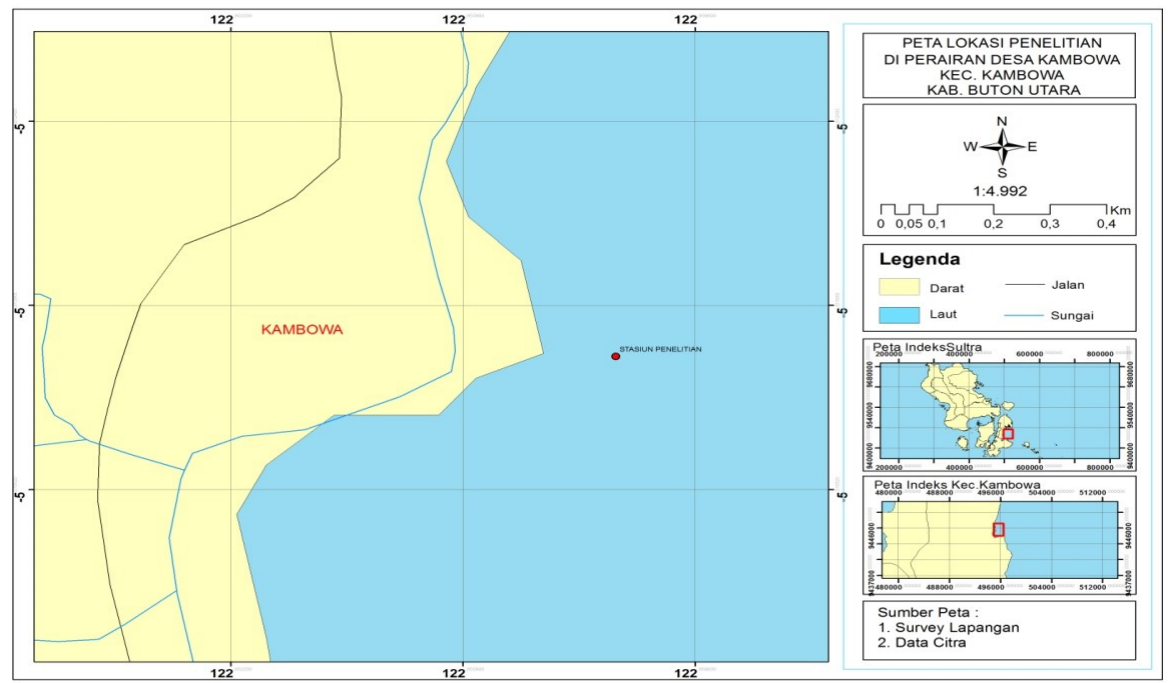

Figure 1 Lokasi penelitian di perairan Desa Kambowa

kelas, yaitu Chlorophyta 6 jenis, Phaeophyta 5 jenis, Rhodophyta 5 jenis (Tabel 1). Makroalga yang ditemukan paling banyak di perairan Desa Kambowa berasal dari kelas Chlorophyta 6 jenis sementara kelas Phaeophyta dan Rhodophyta masing-masing 5 jenis. Hasil penelitian Fadhillah (2010) di perairan Pantai Lakeba, jenis makroalga yang diperoleh 16 jenis, 5 jenis dari kelas Chlorophyta, 6 jenis kelas Phaeophyta dan 5 jenis kelas Rhodophyta. Penelitian Umasagi (2001) di perairan pantai Desa Tanjung Tiram, menemukan 19 jenis , 7 jenis kelas Chlorophya, 5 jenis kelas Phaeophya dan 7 jenis kelas Rhodophyta. Perbedaan hasil makroalga yang ditemukan disebabkan oleh pengaruh substrat yang berbeda. Ini sesuai ini dengan pernyataan Kadi (2000), kehadiran makroalga menunjukkan bahwa kombinasi struktur substrat sangat menentukan variasi spesies makroalga yang ada. Kondisi substrat di Pantai Lakeba yaitu pasir berbatu sedangkan di pantai Desa Tanjung Tiram substratnya pasir sangat kasar dan pecahan karang maupun moluska. Kondisi substrat di perairan Desa Kambowa berupa batuan dan rataan terumbu.

Perbedaan jumlah spesies makroalga dipengaruhi oleh faktor kondisi lingkungan yang mendukung kemampuan adaptasi dari masing-masing spesies. Perbedaan jumlah spesies makroalga dipengaruhi oleh beberapa faktor yaitu daya reproduksi yang tinggi, kemampuan adaptasi yang berkembang, daya tahan yang lemah terhadap habitat, adanya predator dan penyakit (McNaughton and Wolf, 1990). Jenis-jenis makroalga di perairan Desa Kambowa merupakan jenis yang telah beradaptasi dengan kondisi pantai yang sering mengalami kekeringan karena pantainya yang berupa batuan dan rataan terumbu yang mengalami keterbukaan terhadap udara dan pengaruh ombak besar. Hal ini didukung oleh pendapat Kadi (2004), bahwa substrat paparan terumbu yang relatif dekat dengan bagian daratan pada waktu air surut terendah, makroalga yang dapat tumbuh memperlihatkan toleransi yang tinggi terhadap kekeringan.

Komposisi jenis makroalga yang ditemukan terdiri atas kelas Chlorophyta sebesar $42 \%$ disusul kelas Phaeophyta sebesar 37\% dan kelas Rhodophyta sebesar $21 \%$. Tingginya persentase kelas Chlorophyta disebabkan karena kelas ini lebih banyak hidup dekat dengan daratan atau dengan kedalaman perairan yang rendah, sehingga lebih banyak memperoleh intensitas matahari untuk proses fotosintesis. Alga chlorophyta tersebar di perairan pantai, lebih ke tengah phaeophyta dan lebih ke dalam lagi rhodophyta. Persentase komposisi kelas makroalga dapat dilihat pada Gambar 2.

Total kepadatan makroalga yang ditemukan di perairan Desa Kambowa sebesar 542 ind $/ \mathrm{m}^{2}$ yang terdiri atas kelas Chlorophyta sebesar 229 ind $/ \mathrm{m}^{2}$, kelas Phaeophyta dan Rhodophyta masing masing sebesar $201 \mathrm{ind} / \mathrm{m}^{2}$ dan $112 \mathrm{ind} / \mathrm{m}^{2}$. Kepadatan suatu organisme ditentukan oleh kemampuan menyesuaikan diri dengan lingkun- 
Table 1 Jenis-jenis makroalga di perairan Desa Kambowa

\begin{tabular}{|c|c|c|c|c|c|}
\hline No & Kelas & Ordo & Famili & Genus & Spesies \\
\hline 1 & \multirow{6}{*}{ Chlorophyta } & \multirow{2}{*}{ Siphonales } & \multirow{2}{*}{ Caulerpaceae } & \multirow{2}{*}{ Caulerpa } & Caulerpa serrulata \\
\hline 2 & & & & & Caulerpa racemosa \\
\hline 3 & & \multirow{2}{*}{ Dasycladales } & Halimedaceae & Halimeda & Halimeda macroloba \\
\hline 4 & & & Dasycladaceae & Neomeris & Neomeris annulata \\
\hline 5 & & \multirow{2}{*}{ Cladophorales } & Cladophoraceae & Chaetomorpha & Chaetomorpha crassa \\
\hline 6 & & & Siphonocladaceae & Boergesenia & Boergesenia forbesii \\
\hline 7 & \multirow{5}{*}{ Phaeophyta } & \multirow{5}{*}{ Fucales } & \multirow{2}{*}{ Dictyotaceae } & \multirow{2}{*}{ Padina } & Padina minor \\
\hline 8 & & & & & Padina pavonica \\
\hline 9 & & & \multirow{3}{*}{ Sargassaceae } & \multirow{2}{*}{ Turbinaria } & Turbinaria ornata \\
\hline 10 & & & & & Turbinaria $s p$ \\
\hline 11 & & & & Sargassum & Sargassum crassifolium \\
\hline 12 & \multirow{5}{*}{ Rhodophyta } & \multirow{2}{*}{ Ceramiales } & \multirow{2}{*}{ Rhodymeniaceae } & Laurencia & Laurencia complanata \\
\hline 13 & & & & Amansia & Amansia glomerata \\
\hline 14 & & \multirow{2}{*}{ Corallinales } & \multirow{2}{*}{ Corallinaceae } & Ampiroa & Amphiroa fragillisima \\
\hline 15 & & & & Jania & Jania $s p$ \\
\hline 16 & & Gigartinales & Soleriaceae & Gracillaria & Glacillaria edulis \\
\hline
\end{tabular}

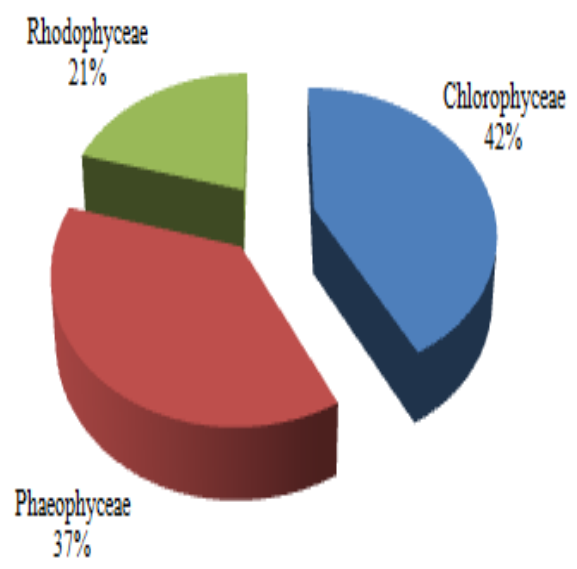

Figure 2 Komposisi kelas makroalga di perairan Desa Kambowa

gan tempat organisme itu hidup. Kepadatan tertinggi pada kelas Chlorophyta adalah Halimeda macroloba sebanyak $144 \mathrm{ind} / \mathrm{m}^{2}$ begitupula dari hasil perhitungan frekuensi, menunjukkan bahwa $H$. macroloba merupakan jenis yang mempunyai frekuensi yang paling tinggi yaitu sebesar 0,50 . Ini menunjukkan bahwa peluang kehadiran jenis ini disetiap kuadran pengamatan cukup tinggi. Sedangkan jenis yang mempunyai frekuensi terendah adalah Caulerpa serrulata sebesar 0,13 dengan kepadatan $10 \mathrm{ind} / \mathrm{m}^{2}$. Kepadatan dan frekuensi makroalga dapat dilihat pada Tabel 2.

Jenis Halimeda (H. macroloba) memiliki kepadatan dan frekuensi kehadiran yang tinggi disebabkan selain hidup berkelompok, Halimeda memiliki kemampuan daya adaptasi yang cukup
Table 2 Kepadatan dan frekuensi makroalga di perairan Desa Kambowa

\begin{tabular}{|c|c|c|c|}
\hline No & Spesies & $\begin{array}{c}\text { Kepadatan } \\
\text { (ind } / \mathrm{m})^{2}\end{array}$ & Frekuensi \\
\hline \multicolumn{4}{|c|}{ Kelas Chlorophyceae } \\
\hline 1 & Caulerpa serrulata & 10 & 0,13 \\
\hline 2 & Caulerpa racemosa & 24 & 0,30 \\
\hline 3 & Halimeda macroloba & 144 & 0,50 \\
\hline 4 & Neomeris annulata & 19 & 0,20 \\
\hline 5 & Chaetomorpha crassa & 17 & 0,20 \\
\hline 6 & Boergesenia forbesii & 15 & 0,20 \\
\hline \multicolumn{4}{|c|}{ Kelas Phaeophyceae } \\
\hline 7 & Padina minor & 44 & 0,33 \\
\hline 8 & Padina pavonica & 32 & 0,13 \\
\hline 9 & Turbinaria ornata & 26 & 0,20 \\
\hline 10 & Turbinaria $s p$ & 19 & 0,23 \\
\hline 11 & Sargassum crassifolium & 80 & 0,27 \\
\hline \multicolumn{4}{|c|}{ Kelas Rhodophyceae } \\
\hline 12 & Laurencia complanata & 21 & 0,27 \\
\hline 13 & Amansia glomerata & 22 & 0,23 \\
\hline 14 & Amphiroa fragillisima & 51 & 0,37 \\
\hline 15 & Jania $s p$ & 16 & 0,20 \\
\hline \multirow[t]{2}{*}{16} & Glacillaria edulis & 2 & 0,07 \\
\hline & Jumlah & 542 & 3,83 \\
\hline
\end{tabular}

tinggi terhadap lingkungan. Kemampuan adaptasi yang cukup tinggi tersebut menyebabkan penyebarannya luas. Hal ini sesuai dengan pendapat Morthon (1990), bahwa jenis Halimeda merupakan alga hijau tropis yang paling luas distribusinya. Didukung pula oleh pendapat Atmadja et al. (2006), makroalga Halimeda mempunyai toleransi yang luas terhadap lingkungan, dimana dapat terekspos selama satu hari dan dapat tumbuh pada berbagai substrat. Halimeda telah beradaptasi untuk tumbuh dan berkembang di kondisi pantai desa Kambowa yang sering terpapar kekeringan dan ombak besar. 
Jenis Caulerpa serrulata memiliki sebaran yang tidak begitu luas.

Jenis Sargassum crassifolium memiliki kepadatan tertinggi pada kelas Phaeophyta sebesar $80 \mathrm{ind} / \mathrm{m}^{2}$, namun memiliki frekuensi kehadiran lebih rendah dibandingkan jenis Padina minor yang memiliki kepadatan sebesar $44 \mathrm{ind} / \mathrm{m}^{2}$. Frekuensi kehadiran $P$. minor sebesar 0,33 sedangkan $S$. crassifolium sebesar 0,27. Ini menunjukkan bahwa jenis $P$. minor memiliki penyebaran yang lebih luas dibandingkan $S$. crassifolium. Padina mampu bertahan hidup baik dalam keadaan terendam air maupun terekspos udara terbuka, seperti di perairan Desa Kambowa dimana kondisi pantainya saat surut terpapar langsung oleh matahari dan musim timur terkena ombak besar. Menurut Kadi (2004), Padina tumbuh menempel di batu pada daerah terumbu karang, baik di tempat terbuka di laut maupun di tempat terlindung.

Sementara Sargassum merupakan salah satu jenis makroalga yang bersifat musiman. Menurut Wong and Phang (2004) kepadatan makroalga sangat dipengaruhi oleh pergantian musim dan kondisi substrat. Sargassum kebanyakan ditemukan di daerah ujung luar rataan terumbu yang terkena ombak. Jenis ini sering terlepas dari substratnya selama ombak besar dan hanyut ke permukaan laut. Sehingga musim-musim tertentu kadang kepadatannya tinggi dan kadang pula kepadatannya rendah. Di substrat paparan yang berbatu karang merupakan tempat untuk melekatkan thallus selama pertumbuhan berlangsung dan sebagai tempat melekat perkecambahan spora.

Jenis Amphiroa fragillisima memiliki kepadatan tertinggi pada kelas Rhodophyta yakni sebanyak $51 \mathrm{ind} / \mathrm{m}^{2}$ dan memiliki frekuensi kehadiran tertinggi pula yakni sebesar 0,37. Kepadatan terendah adalah Gracillaria edulis sebesar 2 $\mathrm{ind} / \mathrm{m}^{2}$ dengan frekuensi kehadiran rendah yakni sebesar 0,07. Hal ini menunjukkan bahwa Amphiroa fragilissima memiliki sebaran yang lebih luas dibandingkan dengan $G$. edulis. Jenis $A$. fragilissima dapat tumbuh menempel pada batu di rataan pasir maupun rataan terumbu. A. fragilissima tumbuh pada batu di daerah rataan pasir atau menempel pada substrat dasar dan menyebar di daerah padang lamun maupun terumbu karang. Sementara G. edulis hidup menempel
Table 3 Nilai rataan dan kisaran kualitas air

\begin{tabular}{cccc}
\hline No & Parameter lingkungan & Satuan & Kisaran \\
\hline 1 & Suhu & ${ }^{o} \mathrm{C}$ & 31 \\
2 & $\mathrm{pH}$ & & 7 \\
3 & Kecerahan & $\%$ & 100 \\
4 & Kedalaman & $\mathrm{cm}$ & $2-289$ \\
5 & Kecepatan arus & $\mathrm{m} / \mathrm{det}$ & $0,014-0,015$ \\
\hline
\end{tabular}

pada substrat berbatu dan sering terlepas karena tidak kuat menempel pada substrat. Spesies alga ini biasanya sering terdampar ke pantai karena tidak kuat menempel pada substrat sehingga mudah terbawah oleh ombak.

Keberadaan makroalga juga dipengaruhi oleh faktor kualitas perairan seperti suhu, $\mathrm{pH}$, kedalaman perairan, kecerahan dan kecepatan arus. Kualitas lingkungan di perairan Desa Kambowa dapat dilihat pada Tabel 3.

Suhu yang terukur di Perairan Desa Kambowa berkisar $31^{\circ} \mathrm{C}$. Nilai ini masih mendukung untuk pertumbuhan makroalga. Menurut Dawes (1981) kisaran suhu normal untuk pertumbuhan makroalga adalah $25-35^{\circ} \mathrm{C}$. Perubahan suhu yang ekstrim akan mengakibatkan kematian bagi makroalga, terganggunya tahap-tahap reproduksi dan terhambatnya pertumbuhan (Chapman, 1997). Selanjutnya menurut Lüning (1990), secara fisiologis, suhu rendah mengakibatkan aktifitas biokimia dalam tubuh thalus berhenti, sedangkan suhu yang terlalu tinggi akan mengakibatkan rusaknya enzim dan hancurnya mekanisme biokimiawi dalam thalus makroalga.

Derajat keasaman ( $\mathrm{pH}$ ) mempengaruhi pertumbuhan alga. $\mathrm{pH}$ yang terukur di lokasi penelitian adalah 7. Nilai ini masih mendukung untuk pertumbuhan makroalga. Menurut Marianingsih et al. (2013) pertumbuhan makroalga dapat berlangsung terus-menerus pada kisaran $\mathrm{pH}$ 7-8. Menurut Serdiati and Widiastuti (2010) $\mathrm{pH}$ yang baik untuk makroalga dengan tingkat potensi lahan yang sesuai adalah 7-8,5.

Kedalaman perairan yang terukur di perairan Desa Kambowa yaitu 2-289 cm. Kedalaman perairan ini masih dapat dijangkau oleh penetrasi cahaya. Hasil pengukuran kecerahan mencapai $100 \%$. Makroalga membutuhkan cahaya matahari untuk membantu proses fotosintesis yang terjadi di dalam tubuh makroalga. Penyerapan cahaya matahari dapat terjadi karena adanya pigmen fotosintesis dan pigmen asesoris 
yang berperan dalam menerima energi cahaya matahari untuk ditrasfer ke klorofil.

Kecepatan arus yang terukur di perairan Desa Kambowa berkisar 0,014-0,015 m/dtk. Nilai ini termasuk dalam kategori lambat dan tenang. Pengambilan data dilaksanakan ketika perairan Desa Kambowa mengalami musim teduh (musim barat). Musim barat terjadi sekitar bulan NovemberMaret. Kecepatan arus yang lambat menyebabkan thallus mudah ditempeli kotoran sehingga proses fotosintesis akan terhambat dan mengakibatkan pertumbuhan makroalga menjadi lambat. Menurut Atmadja et al. (2006) pergerakan air yang baik untuk pertumbuhan makroalga adalah 0,033 $0,066 \mathrm{~m} / \mathrm{dtk}$.

\section{SIMPULAN}

Jumlah jenis makroalga yang ditemukan terdiri atas 16 spesies yang terdiri atas 7 ordo, 10 famili, 13 genus. Komposisi jenis makroalga didominasi oleh kelas Chlorophyta, kelas Phaeophyta dan kelas Rhodophyta.

\section{References}

Atmadja, W. S., Kadi, A., Sulistijo, and Rachmaniar (2006). Pengenalan jenis-jenis rumput laut di indonesia. Technical report, Pusat Penelitian dan Pengembangan Oseanologi-LIPI.

Brower, J. E., Zar, J. H., and Ende, C. V. (1998). Ekologi Umum. Metode Lapangan dan Laboratorium. Wm,C.Brown Company Publisher.

Chapman, A. (1997). Biology of seawead.

Dawes, C. (1981). Marine botany. New York, etc.: John Wiley \& Sons.

Duxbury, A. C. and Fuxbury, A. B. (1989). Oceans and introduction to the world. Wm. C. Publisher.

English, S. S., Wilkinson, C. C., and Baker, V. V. (1997). Survey manual for tropical marine resources. Australian Institute of Marine Science.

Fachrul, M. F. (2007). Metode sampling bioekologi. Bumi Aksara. Jakarta, 13.
Fadhillah, A. (2010). Studi ekologi makroalga di perairan pantai lakeba kota bau-bau. Master's thesis, Universitas Halu Oleo.

Indriani, H. and Sumiarsih, E. (1992). Budidaya, pengelolaan, dan pemasaran rumput laut. Penebar Swadaya.

Kadi, A. (2000). Rumput laut di perairan kalimantan timur.

Kadi, A. (2004). Potensi rumput laut di beberapa perairan pantai indonesia. Oseana, 29(4):25-36.

Lüning, K. (1990). Seaweeds: their environment, biogeography, and ecophysiology. John Wiley \& Sons.

Marianingsih, P., Amelia, E., and Suroto, T. (2013). Inventarisasi dan identifikasi makroalga di perairan pulau untung jawa. Prosiding SEMIRATA 2013, 1(1).

McNaughton, S. and Wolf, L. L. (1990). Ekologi umum. Penerjemah Soenaryo. Gadjah Mada University Press, Yogyakarta.

Serdiati, N. and Widiastuti, I. M. (2010). Pertumbuhan dan produksi rumput laut eucheuma cottonii pada kedalaman penanaman yang berbeda. Media Litbang Sulteng, 3(1).

Umasagi, R. (2001). Kepadatan, pola distribusi dan keanekaragaman rumput laut di perairan pantai desa tanjung tiram kecamatan moramo kabupaten kendari. Master's thesis, Universitas Halu Uleo.

Wong, C. and Phang, S. M. (2004). Diversity and distribution of Malaysian Sargassum species.

Wray, J. L. (2009). Calcareous algae, volume 4. Elsevier.

www. algaebase. org (2018). Database of information on alga that includes terrestrial, marine and freswater organism. 